ACTA MYCOLOGICA

Vol. 48 (2): 197-205

2013
Dedicated to Professor Maria Ławrynowicz on the occasion of the 45th anniversary of her scientific activity

DOI: $10.5586 / \mathrm{am} .2013 .021$

\title{
Melampsoridium hiratsukanum - invasive rust species in Lithuania, and its co-occurrence with eriophylid mite
}

\author{
SVETLANA MARKOVSKAJA \\ Laboratory of Mycology, Institute of Botany, Nature Research Centre, Žaliujų ežerų str. 49 \\ LT-08406 Vilnius 21, svetlana.markovskaja@botanika.lt.
}

Markovskaja S.: Melampsoridium hiratsukanum - invasive rust species in Lithuania, and its cooccurrence with eriophylid mite. Acta Mycol. 48 (2): 197-205, 2013.

An invasive East Asian rust fungus Melampsoridium hiratsukanum, obligate biotroph belonging to Pucciniastraceae, Pucciniales (Basidiomycota) is found widely spread on leaves of Alnus incana in eastern, central and southern parts of Lithuania. On Alnus glutinosa this fungus is rare, sometimes occurring with an alder leaf pest, a microscopic eriophyid gall mite Acalitus brevitarsus. Information on the distribution patterns, ecological and morphological characters of this neomycete is given.

Key words: Pucciniales, biotroph, Melampsoridium hiratsukanum, Alnus, Acalitus brevitarsus, Lithuania

\section{INTRODUCTION}

Majority of pathogenic neomycetes are classified as having considerable negative ecological and economic impact (Pimentel et al. 2001; Desprez-Loustau et al. 2007, 2010; NOBANIS 2007). Alien fungal diseases of woody plants represent a serious risk to forest ecosystems and growing plantations. In the mid-1990ies epidemic of a new foliar rust fungus affecting alder trees appeared in the Baltic region, in Estonia and Finland (Põldmaa 1997; Kurkela et al. 1999) and started to spread rapidly in Europe (Hantula, Scholler 2006). The agent was identified as Melampsoridium hiratsukanum S. Ito ex Hirats. based on morphological characterization and later was confirmed by molecular data (Hantula et al. 2009).

In Lithuania, the fungus appeared at the same time, the first specimen was collected in 1997 in Ukmerge district on Alnus incana (L.) Moench (herbarium data, BILAS 31446). Originally M. hiratsukanum was described in 1927 on Alnus hirsuta (Spach.) Rupr. in Japan (Hiratsuka 1927) and was reported as native species in Far East Asia (Kuprevich, Tranzschel 1957; Hiratsuka et al. 1992; Gjaerum 1996; Chen 2002; Cho, Shin 2004; Kobayashi 2007). M. hiratsukanum represents a heteroecious 
rust fungus belonging to Pucciniastraceae (Pucciniales, Basidiomycota) characterized by macrocyclic host-alternating life mode. Its uredinial and telial stages occur on Alnus spp., while the aecial stage develops on Larix spp. (Kuprevicz, Tranzschel 1957, Kaneko, Hiratsuka 1981; Roll-Hansen, Roll-Hansen 1981).

The detailed comparison of urediospore morphology and r-DNR sequence analysis of the ITS region showed that European population of M. hiratsukanum is conspecific with population of this fungus from Eastern Asia and that both populations belong to a single palearctic population (Hantula et al. 2009). In Europe this aggressive rust commonly cause considerable damage to foliage of grey alder, but may also infect more resistant black alder and cause serious problems in forest stands mixed with larch (Kurkela et al. 1999; Hantula et al. 2009). Introduction of this pathogen may be a result of an unintentional human activity such as transporting propagative plant material and seeds around the world or because of natural climatic factors. Natural migration of $M$. hiratsukanum could be explained by continuity of its main (Alnus spp.) and alternate (Larix spp.) host distribution from the Far East, where it inhabits native for Asia Manchurian alder (Hiratsuka et al. 1992), to Siberia (Kuprevicz, Tranzschel 1957), Fennoscandia, Baltic region and further to Europe, where it occurrs on Eurasian grey and native for Europe black alders as well as on various (Dahurian, Siberian, European) larches (Põldmaa 1997; Kurkela et al. 1999; Hantula et al. 2009; Lilja et al. 2011). Changing climate with milder winters and increased precipitation probably also stimulated invasion and rapid spread of this neomycete in the new regions on new hosts during the last decades.

Nowadays, $M$. hiratsukanum is widely spread in many European countries and is placed in the lists of important invasive species (Hantula, Scholler 2006; Negrean, Anastasiu 2006; NOBANIS 2007; Desprez-Loustau et al. 2007; Desprez-Loustau 2009, Mułenko et al. 2010). The disease it causes is known from Austria (RiglerHager et al. 2003; Kruse 2013), Czech Republic (Dietrich 2005; Müller 2003), Estonia (Põldmaa 1997), Germany (Scholler 1999; Scholler et al. 2010; Kruse 2013); Hungary (Szabo 2002), Finland (Kurkela et al. 1999, Hantula et al. 2009 Lilja et al. 2011), Norway (Gjaerum et al. 2004), Poland (Wołczańska 1999, Piątek et al. 2001; Mułenko et al. 2006, 2008, 2010), Romania (Negrean, Anastasiu 2006), Switzerland (Meier et al. 2003), Turkey (Sert, Sumbul 2005), Italy (Moricca, Maresi 2010), UK (Stringer 2010; Hantula et al. 2012), Ukraine (Tykhonenko 2011) and from both Americas (Dennis 1970; Gallegos, Cummins 1981; Ginns 1986; Buritica, Pardo Cardona 1996; Hernandez, Hennen 2002; Berndt 2004; Hantula et al. 2012).

The main aim of present study was to indicate the occurrence of Melampsoridium hiratsukanum on Alnus spp. in Lithuania, to discuss its ecology and distribution patterns.

\section{MATERIAL AND METHODS}

Samples of the rust infected leaves of Alnus incana (L.) Moench and A. glutinosa (L.) Gaertn. were collected from various regions of Lithuania during the autumn of 20092012. Observation of disease symptoms (Figs 1,2) and severity continued until late October each year concerned. For comparison morphologically similar rusts, infected leaves of nearby growing Betula pendula Roth, which may occur on alder leaves as well, 

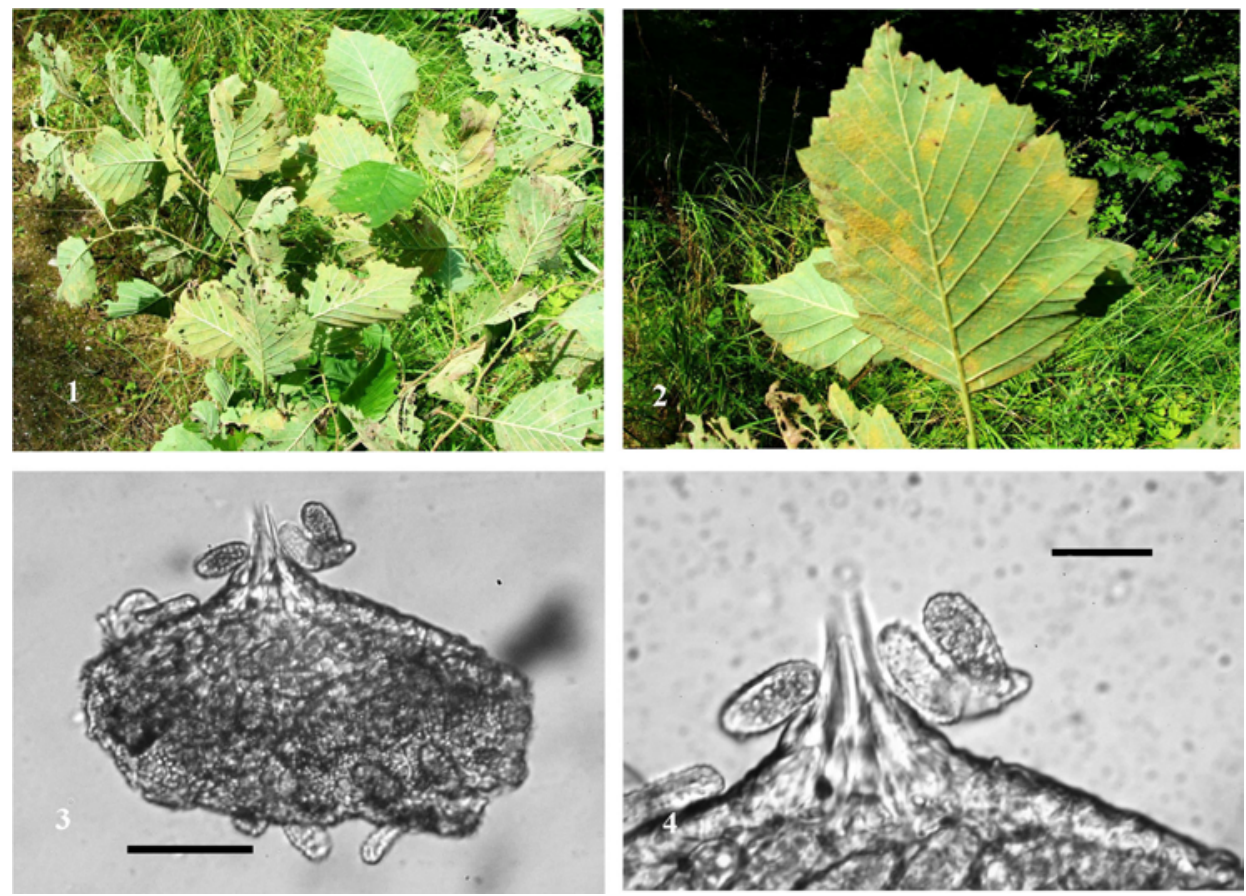

Figs1-4. Rust fungus Melampsoridium hiratsukanum 1-2. Symptoms on upper part of grey alder Alnus incana -leaves (photo by J. Kasparavičius). 3. Melampsoridium hiratsukanum uredinium $($ scale bar $=100 \mu \mathrm{m}) .4$. Ostiolar cells of uredinium and regularly echinulate urediniospores of Melampsoridium hiratsukanum (scale bar $=20 \mu \mathrm{m}$ ).

were collected. Specimens with characteristic rust symptoms collected during present study and all specimens collected earlier by other mycologists available at the herbarium of the Nature Research Centre, Institute of Botany (BILAS), were microscopically examined using the standard microscopic techniques with a Nikon stereo microscope at the magnifications up to 40x and with an Olympus CX 41 microscope at the magnifications up to 400-1000x. The fungus was identified according to morphological characters using (Kuprevich, Tranzschel 1957; Kaneko, Hiratsuka 1981; Roll-Hansen, Roll-Hansen 1981; Hiratsuka et al. 1992; Hantula et al. 2009).

Description and illustrations were made from fresh preparations in distilled water. Dried voucher specimens are preserved in the BILAS Herbarium.

\section{RESULTS AND DISCUSSION}

On alders, three morphologically similar Melampsoridium rusts may occur: $M$. betulinum (Pers.) Kleb, M. hiratsukanum S. Ito ex Hirats. and M. alni (Thüm.) Dietel, but only two of them $-M$. betulinum and M. hiratsukanum are known in Europe so far (Hantula et al. 2009). In Lithuania, M. betulinum is widely spread on birches, but was not yet recorded on alders (Minkevičius, Ignatavičiūte 1991). Microscopical 
Table 1

Comparison of urediniospores of $M$. hiratsukanum and similar rust species occurring on Alnus and Betula hosts from Baltic countries and Japan

\begin{tabular}{|l|l|l|l|}
\hline \multicolumn{1}{|c|}{ Rust species } & \multicolumn{1}{|c|}{ Host } & \multicolumn{1}{c|}{ Country } & \multicolumn{1}{c|}{$\begin{array}{c}\text { Urediniospores length } \\
\text { and width range, } \mu \mathrm{m}\end{array}$} \\
\hline M. hiratsukanum & Alnus incana & Lithuania & $22.6-35.0 \times 11.5-15.5$ \\
\hline M. hiratsukanum & Alnus glutinosa & Lithuania & $20.4-32.6 \times 9.8-16.0$ \\
\hline M. hiratsukanum & Alnus incana & Finland (Kurkela et al. 1999) & $19.2-34.5 \times 10.6-19.6$ \\
\hline M. hiratsukanum & Alnus glutinosa & Finland (Kurkela et al. 1999) & $22.6-35.2 \times 10.9-16.6$ \\
\hline M. hiratsukanum & Alnus incana & Estonia (Kurkela et al. 1999) & $17.9-30.9 \times 10.6-17.3$ \\
\hline M. hiratsukanum & Alnus glutinosa & Estonia (Kurkela et al. 1999) & $20.9-29.2 \times 12.3-16.9$ \\
\hline M. hiratsukanum & Alnus hirsuta & Japan (Hantula et al. 2009) & $17.0-32.6 \times 8.8-19.7$ \\
\hline M. alni & Alnus crispa & Japan (Hantula et al. 2009) & $24.4-43.3 \times 9.1-16.4$ \\
\hline M. betulinum & Betula pendula & Finland (Kurkela et al. 1999) & $26.5-42.1 \times 11.6-19.9$ \\
\hline M. betulinum & Betula pendula & Lithuania & $28.0-42.5 \times 11.5-18.4$ \\
\hline M. betulinum & Betula pubescens & $\begin{array}{l}\text { Lithuania (Minkevičiüs, } \\
\text { Ignatavičiūte 1991) }\end{array}$ & $(18) 26.2-32.1(50.0) \times$ \\
\hline M. betulinum & Betula pubescens & Finland (Kurkela et al. 1999) & $25.4-45.7-13.9(17.0)$ \\
\hline M. betulinum & Betula pubescens & Estonia (Kurkela et al. 1999) & $24.9-38.5 \times 11.9-17.2$ \\
\hline
\end{tabular}

examination of Lithuanian material showed that the rust developing on leaves of Alnus incana and on leaves of $A$. glutinosa produced regularly echinulate yelloworange, ovoid to ellipsoidal urediniospores, commonly $24-32 \times 12-15 \mu \mathrm{m}$ in size with 4-6 bizonate germ pores and by size and morphology differs both from native rust $M$. betulinum and other Asian alder rust, M. alni (Tab. 1). Following morphological characters of uredinia and urediospores the rust obtained on Alnus leaves in Lithuania was identified as $M$. hiratsukanum (Figs 3-4). Uredinia of M. hiratsukanum produced longer, resembling sharp spines, ostiolar cells (up to $50 \mu \mathrm{m}$ ), comparing to morphologically similar M. betulinum. Uredinia of $M$. betulinum collected during present study were characterized by shorter ostiolar cells (up to $35 \mu \mathrm{m}$ long) and by smooth, rounded upper end of urediniospores, which were slightly larger in size, commonly about $26-48 \times 12-17 \mu \mathrm{m}$. M. alni is very similar to M. betulinum by size of urediniospores and lack of echinulation at the apex but its urediniospores have two germ pores, one at each end of the spore (Hiratsuka 1927; Kuprevich, Tranzschel 1957; Hantula et al. 2009).

During present investigation, Larix spp. trees were checked in various parks and forest plantations as well, but aecial stage of $M$. hiratsukanum was not found. It is possible that the fungus can reproduce and spread only by its urediniospores (Hantula, Scholler 2006). Apparently, reduced fungus life cycle restricted to the telial and uredinal host (Alnus spp.) prevails in Lithuania.

EXAMINED SPECIMENS: Melampsoridium hiratsukanum: on Alnus incana, Gružu forest, Ukmergè distr., 10 Sep., 1997, leg. A.Treigienè, det. Ignatavičiūtè, BILAS 31446; on A. incana, Vilainiai forest Kèdainiai distr., 16 Sep., 1998, leg. A.Treigienè, det. Ignatavičiūtė; BILAS 31445; on A. incana, Plateliai forest, Plungè distr., 3 Sep., 2003, leg. A.Treigienè, det. S. Markovskaja, BILAS 48792 on A. incana, Semeliškiai environs, Liaukiškiai forest, Trakai distr., 6 Sep., 2005, leg.A. Treigienè, det. S. Markovskaja, BILAS 32914; on A. incana, Vidiškiai forest, Ignalina distr., 28 Aug., 2009, leg./det. S. Markovskaja, BILAS 48794; on A. incana, Biržai forest, Biržai distr., 27 Sep., 2009, leg./det. S. Markovskaja, BILAS 48795; on A. incana, Sirvètos forest, Švenčionys distr., 29 Aug., 2009, leg./det. S. Markovskaja, BILAS 48797; on 
A. incana, Labanoras forest, Molètai distr., 28 Aug., 2009, leg./det. S. Markovskaja, BILAS 48798; on A. incana, Pabradè environs, Švenčionys distr., 29 Aug., 2009, leg./ det. S. Markovskaja, BILAS 48796; on A. incana, Curonian Spit, Neringa, Smiltynè, 8 Sep. 2009, leg./det. S. Markovskaja, BILAS 48791; M. hiratsukanum on Alnus incana, Vabalininkų environs, Panevežys distr., 26 Aug., 2009, leg./det. S. Markovskaja, BILAS 49521; on A. incana, Petriškiai forest, Širvintai distr., 10 Oct., 2010, leg. A. Treigienè, det. S. Markovskaja, BILAS 48932; on A. incana, Jurkiškiai forest, Molètai distr., 22 Sep., 2011, leg./det. S. Markovskaja, BILAS 50311; on A. incana, Akmena environs, Vilnius distr., 23 Sep., 2011, leg./det. S. Markovskaja, BILAS 50309; on $A$. incana, Antaviliai forest, Vilnius distr., 5 Sep., 2011, leg./det. S. Markovskaja, BILAS 50310; on A. incana, Curonian Spit, Neringa, Juodkrantė environs, 4 Sep. 2012, leg./ det. S. Markovskaja, BILAS 50314; on A. incana, shoreline of Curonian Lagoon, Klaipèda distr. 9 Sep. 2012, leg./det. S. Markovskaja, BILAS 50312; on A. incana, Aukštadvarys environs, Trakai distr., 11 Oct., 2012, leg./det. S. Markovskaja, BILAS 50316; on A. incana, Rudninkai forest, Šalčininkai distr., 21 Aug., 2012, leg./det. S. Markovskaja, BILAS 50315; on $A$. incana, Čepkeliai forest, Varèna distr., 8 Sep., 2012, leg./det. S. Markovskaja, BILAS 50317 on A. incana, Kaunas environs, Kaunas distr., 6 Sep., 2012, leg./det. S. Markovskaja, BILAS 50318; on Alnus glutinosa, together with Acalitus brevitarsus Fockeu, Juodkrante environs, Neringa, Curonian Spit, 4 Sep. 2010, leg./det. S. Markovskaja, BILAS 48933; on A. glutinosa, environs of Lake Tabaliukai, Trakai district, 11 Oct., 2012, leg./det. S. Markovskaja, BILAS 50313; Melampsoridium betulinum: on Betula pendula, Kretinga environs, Kretinga distr., 27 Aug. 1971, leg. B. Grigaliūnaitè, det. L. Šidla, BILAS 31443; M. betulinum on B. pendula, Smiltynè forest, Neringa, Curonian Spit, 9 Sep. 2009, leg./det. A. Treigiené, BILAS 48458; M. betulinum on B. pendula Smiltynè forest, Neringa, Curonian Spit, 8 Sep. 2011, leg./det. S.Markovskaja, BILAS 48459; M. betulinum on

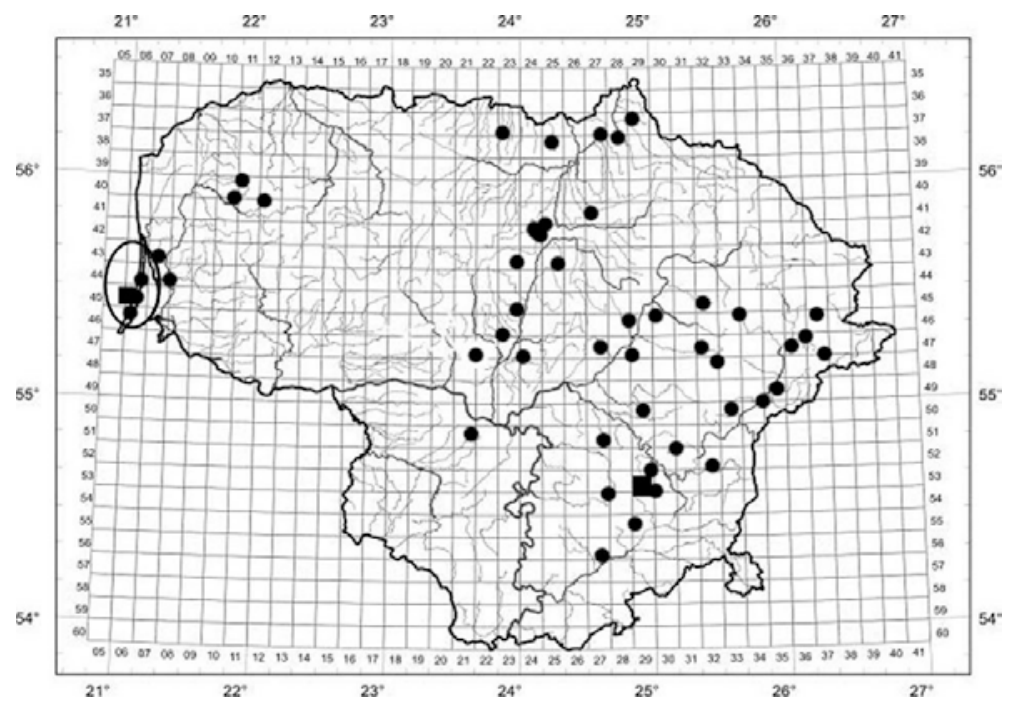

Fig. 5. Distribution map of Melampsoridium hiratsukanum in Lithuania ( - on Alnus incana, - on Alnus glutinosa). The locality of the great cormorant colony (Curonian Spit, area in which M. hiratsukanum co-occurred with Acalitus brevitarsus) is marked by ellipse. 
B. pendula, Juodkrantè environs, Neringa, Curonian Spit, 5 Sep. 2012, leg./det. S. Markovskaja, BILAS 50319.

DistRiBution in LithuANiA. After inspecting mixed forest stands, parks and other habitats in various regions of Lithuania, it was assessed that $M$. hiratsukanum is already widely spread in the country on Alnus incana (leaves' infection in some cases reached 20 to $80 \%$ ) while on A. glutinosa it has appeared recently and does not cause strong damage of leaves (about 10\%). Most strongly infected (up to $60-80 \%$ of leaves) and defoliated already in September were juvenile grey alder trees growing along roads and water bodies. From 2009 till 2012, M. hiratsukanum was recorded on Alnus incana in 22 localities of Biržai, Kaunas Kèdainiai, Klaipèda, Kretinga, Molètai, Ignalina, Panevežys, Plungè, Šalčininkai, Širvintai, Švenčionys, Ukmergè, Trakai, and Vilnius districts, while on Alnus glutinosa it was found only twice, for the first time in 2010 at the edge of the great cormorant (Phalacrocorax carbo sinensis) colony (Curonian Spit, environs of Juodkrantė) and later, in 2012, in the environs of Lake Tabaliukai, Trakai district (Fig. 5).
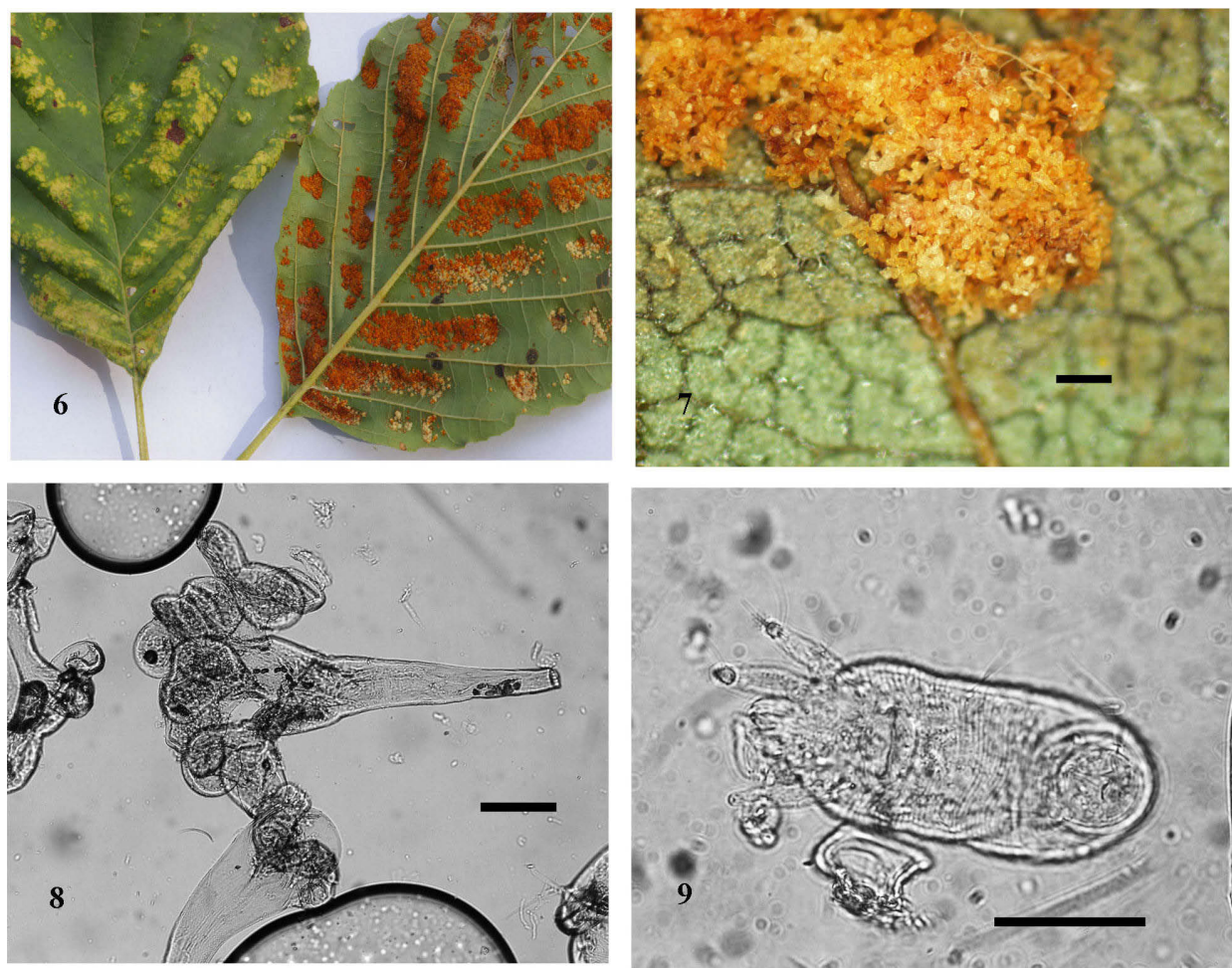

Figs 6-9. Acalitus brevitarsus. 6. Deformation of Alnus glutinosa leaves or blister-like galls and erineum (photo by R. Iršènaitè). 7. Erineum - clusters of hairs on an upper leaf surface (Scale bar $=10 \mathrm{~mm}$, photo by P. Frey from Lithuanian material). 8. An erineum hairs produced by leaf infested by mite (scale bar $=20 \mu \mathrm{m}$, photo by P. Frey from Lithuanian material). 9 . Microscopic mite Acalitus brevitarsus (scale bar $=100 \mu \mathrm{m}$, photo by P. Frey from Lithuanian material). 
Notable, that in Curonian Spit, in the forest stand affected by great cormorant colony, $M$. hiratsukanum infected leaves of both $A$. incana and $A$. glutinosa trees growing nearby and in some cases $M$. hiratsukanum infected Alnus glutinosa leaves together with an alder pest, microscopic mite Acalitus brevitarsus Fockeu. Symptoms caused on leaves by $A$. brevitarsus resemble rust fungus infection. This small arthropode, eriophyid mite (Eriophyidae, Acari, Arthropoda) inhabit exclusively Alnus glutinosa leaves (Figs 6-9). Like many gall-inducing mites, individuals of $A$. brevitarsus cause deformation of leaves or blister-like galls and elicit growth of clusters of hairs on upper surface of leaf (called an erineum) among which the mites live (Figs 6, 7). The hairs have several near-horizontal branches at the tip (Fig. 8), so each group of hairs is like a forest with a closed canopy. Both the pest $A$. brevitarsus and the rust fungus $M$. hiratsukanum were recorded together on the same host leaves only in the stand affected by cormorants (Curonian Spit). In the other parts of Curonian Spit and in the continental part of Lithuania they have never been found to occur together. Evidently, the trees affected by cormorant excrements became less resistant to various pathogens and pests. Successive infections of both agents can cause considerable damage to alder foliage and thus negatively influence the tree health and the functioning of the whole forest ecosystem.

\section{CONCLUSION}

Comparison of morphological data indicated that alders and birches in Lithuania are infected by different rust species. Leaves of Alnus incana and A. glutinosa are damaged by invasive Asian rust $M$. hiratsukanum, while native $M$. betulinum inhabits birch leaves. From its first record in 1997 till now M. hiratsukanum has widely spread in Lithuania on A. incana. On A. glutinosa M. hiratsukanum was recorded for the first time in 2010, co-occurring with eriophyid mite Acalitus brevitarsus. It is hypothesized that the successive colonization and co-occurrence of new pathogen (M. hiratsukanum) and pest (Acalitus brevitarsus) on back alder was a result to the changes (decrease of trees resistance) caused by a strong negative impact of great cormorant colony, namely by forest hypertrophication from the bird excrements.

Acknowledgements. It is a great pleasure and honor to dedicate this paper to Professor Maria Lawrynowicz. Special thanks for help in identifying and making a photograph of the eriophyid gall mite Acalitus brevitarsus are addressed to Dr. Pascal Frey, and to my colleagues Reda Iršènaitė and Jonas Kasparavičius for help during field trips. Anonymous reviewers are thanked for their critical comments and suggestions. This research was funded by a grant no. LEK-03/2012 from the Research Council of Lithuania. 


\section{REFERENCES}

Berndt R. 2004. A checklist of Costa Rican rust fungi. (In:) R. Agerer, M. Piepenbring, P. Blanz (eds). Frontiers in Basidiomycote mycology. IHW-Verlag: 185-236.

Buritica P., Pardo Cardona V.M. 1996. Flora Uredineana Colombiana. Rev. Acad. Colomb. Cienc. 20:183-236.

Chen M.M. 2002. Forest fungi phytogeography: Forest fungi phytogeography of China, North America, and Siberia and international quarantine of tree pathogens. Pacific Mushroom Research and Education Center, Sacramento, California.

Cho W.D., Shin H.D. 2004. List of plant diseases in Korea. Fourth edition. Korean Society of Plant Pathology.

Desprez-Loustau M.L. 2009. Alien fungi in Europe. (In:) P.E. Hulme, W. Nentwig, P. Pyšek, M. Vilŕ (eds). DAISIE. Handbook of Alien Species in Europe. Springer Science + Buisness Media B.V.: 15-28.

Desprez-Loustau M.L., Robin C., Buée M., Courtecuisse R., Garbaye J., Suffert F., Sache I., Rizzo D. 2007. The fungal dimension of biological invasions. Trends Ecol. Evol. 22:472-480.

Dennis R.W.G. 1970. Kew Bulletin Additional Series III. Fungus Flora of Venezuela and Adjacent Countries. Verlag von J. Cramer.

Dietrich W. 2005. The rust fungi, smut fungi and downy mildews in the Czech part of Krusne hory (Erzgebirge): first supplement. Czech Mycol. 57: 257-273.

Gallegos M.L., Cummins G.B. 1981. Uredinales (royas) de Mexico. 2. Instituto Nacional de Investigaciones Agricoles, Culiacan, Sinaloa, Mexico

Ginns J.H. 1986. Compendium of plant disease and decay fungi in Canada 1960-1980. Res. Br. Can. Agric. Publ. 1813: 416.

Gjaerum H.B. 1996. Rust Fungi (Uredinales) from Khabarovsk, Russia. Lidia 3: 173-194.

Gjaerum H.B., Lye K.A., Solheim H. 2004. First record of Melampsoridium hiratsukanum on alder in Norway. Plant Pathol. 53: 530.

Hantula J., Scholler M. 2006. NOBANIS - Invasive Alien Species Fact Sheet - Melampsoridium hiratsukanum. www.nobanis.org., Date of access 02/06/2013.

Hantula J., Nigel Stringer R., Lilja A., Kurkela T. 2012. Alder rust, Melampsoridium hiratsukanum Ito, identified from Wales, UK and British Columbia, Canada. Forest Pathol. 42 (4): 348-350.

Hantula J., Kurkela T., Hendry S., Yamaguchi T. 2009. Morphological measurements and ITS sequences show that the new alder rust in Europe is conspecific with Melampsoridium hiratsukanum in eastern Asia. Mycologia 101 (5): 622-631. http://dx.doi.org/10.3852\%2F07-164

Hernandez J. R., Hennen J. F. 2002. Rust fungi (Uredinales) of nortwest Argentina. Sida 20: 313-338.

Hiratsuka N. 1927. Studies on the Melampsoraceae of Japan. J. Fac Agric, Hokkaido Imp Univ Sapporo, 21: $1-41$.

Hiratsuka N., Sato S., Datsuya K., Kakishima M., Hiratsuka Y., Kaneko S., Ono Y., Sato T., Harada Y., Hiratsuka T., Nakayama K. 1992. The rust flora of Japan. Tsukuba Shuppankai, Takezono, Ibaraki.

Kaneko S., Hiratsuka N. 1981. Classification of the Melampsoridium species based on the position of urediniospore germ porès. Trans. Mycol. Soc. Japan 22: 463-473.

Kobayashi T. 2007. Index of fungi inhabiting woody plants in Japan. Host, Distribution and Literature. Zenkoku-Noson-Kyoiku Kyokai Publishing Co.

Kuprevich V.T., Tranzschel V. 1957. Flora plantarum cryptogamarum URSS. 4. Fungi (1) Uredinales. Fasc. 1. Familia Melampsoraceae. Moscow: Typis et Impensis Academiae Scientiarum URSS.

Kurkela T., Hanso M., Hantula J. 1999. Differentiating characteristics between Melampsoridium rusts infecting birch and alder leaves. Mycologia 91: 987-992. http://dx.doi.org/10.2307\%2F3761629

Kruse J. 2013. Phytoparasitic microfungi of the Berchtesgaden and Salzburg Alps with special emphasis on the National Park Berchtesgaden. Z. Mykol. 79: 99-175.

Lilja A., Rytkönen A., Hantula J., Müller M., Parikka P., Kurkela T. 2011. Introduced pathogens found on ornamentals, strawberry and trees in Finland over the past 20 years. Acricultural and food science 20: 74-85.

Meier F., Engesser R., Forster B., Odermatt O. 2003. Forstschutz-Überblick 2002. Eidgenössische Forschungsanstalt WSL. Birmersdorf. Switzerland. 24 pp.

Minkevičius A., Ignatavičiūtė M. 1991. Lietuvos grybai V. Rūdiečiai 1 (Uredinales),Vilnius.

Moricca S., Maresi G. 2010. Melampsoridium hiratsukanum reported for the first time on grey alder in Italy. New Disease Reports 21:17. 
Mułenko W., Bacigalová K., Kozłowska M. 2006. Parasitic microfungi of the Tatra Mountains 4. Melampsoridium hiratsukanum (Urediniomycetes). Pol. Bot. Stud. 22: 399-405.

Mułenko W., Majewski T., Ruszkiewicz-Michalska M. 2008. A Preliminary Checklist of Micromycetes in Poland. W. Szafer Institute of Botany, Polish Academy of Sciences 9: 752.

Müller J. 2003. Rusts, smuts and downy mildews new for Moravia and Czech Silesia. Czech Mycology 55(3/4): 277-290.

Negrean G., Anastasiu P. 2006. Invasive and potentially invasive parasite neomycetes from Romania. Plant, fungal and habitat diversity investigation and conservation. Proceedings of IV BBC, Sofia: 514-519.

NOBANIS, 2007. North Europiean and Baltic network on invasive alien species. www.nobanis.org. Date of access 02/05/2013.

Piątek M., Ronikier M., Miśkiewicz A. 2001. New records and new host for Melampsoridium hiratsukanum (Fungi, Uredinales) in Poland. Fragm. Flor. Geobot. Polonica 8: 245-249.

Pimentel D., McNair S., Janecka J., Wightman J., Simmonds C., O’Connell C., Wong E., Russel L., Zern J., Aquino T., Tsomondo T. 2001. Economic and environmental threats of alien plant, animal and microbe invasions. Agr. Ecocyst. Environ 84:1-20.

Põldmaa K. 1997. Explosion of Melampsoridium sp. on Alnus incana. Folia Cryptog. Estonica 31: 48-50.

Rigler-Hager H., Scheuer C., Zwetko P. 2003. Der Erlen-Rost Melampsoridium hiratsukanum in Österreich, Wulfenia 10: 135-143.

Roll-Hansen F., Roll-Hansen H. 1981. Melampsoridium on Alnus in Europe. M. alni conspecific with M. betulinum. Eur. J. For. Pathol. 11: 77-87.

Sert H., Sumbul H., 2005. First report of Melampsoridium hiratsukanum infecting alders (Alnus orientalis var. orientalis) in Turkey. Plant Pathology 54 (2): 241. http://dx.doi.org/10.1111\%2Fj.13653059.2005.01131.x

Scholler M. 1999. Obligate phytoparasitic neomycetes in Germany: Diversity, distribution, introduction patterns, and consequences. (In:) U. Doyle (ed.). Alien organisms in Germany. Documentation of a Conference on March 6-7, 1998. "Legal regulations concerning Alien Organisms in Comparison to genetically modified Organisms." Texte des Umweltbundesamtes. 18: 64-75.

Scholler M., Besl, H., Bresinsky A. 2010. Additions to the rust flora of Bavaria. Z. Mykol. 76: 171-176.

Stringer R.N. 2010. New rust for Pembrokeshire. Pembrokeshire Fungus Recorder. 1: 4-5.

Szabo I. 2002. First report of Melampsoridium hiratsukanum on common alder in Hungary. Plant Pathology 51: 804. http://dx.doi.org/10.1046\%2Fj.1365-3059.2002.00776.x

Wołczańska A. 1999. Melampsoridium hiratsukanum (Uredinales), a new species for Poland. Acta Mycol. 34: 345-347. 